Jurnal Informatika dan Rekayasa Perangkat Lunak (JATIKA)
Vol. 1, No. 2, December 2020, 254-263
ISSN 2723-3367
available online at:http:///jim.teknokrat.ac.id/index.php/informatika

\title{
SISTEM INFORMASI PELAYANAN DISTRIBUSI KEUANGAN DESA UNTUK PEMBANGUNAN (STUDY KASUS : DUSUN SRIKAYA)
}

\author{
Sinta Yana ${ }^{1}$, Rakhmat Dedi Gunawan ${ }^{2}$, Arief Budiman ${ }^{3}$ \\ Universitas Teknokrat Indonesia ${ }^{1,2,3}$ \\ sintayana@gmail.com
}

Received: (30 Desember 2020)Accepted: (31 Desember 2020) Published: (31 Desember 2020)

\begin{abstract}
Village funds come from the state revenue and expenditure budget which is regulated by Indonesian government regulation number 60 of 2014. These funds are used for village activities and development. In some situation the use of the Village Fund Allocation is prone to misappropriation of funds by parties that should be trusted by the community in developing a more developed and developing village. The importance of the role of the community as direct supervisors and cannot be separated from the role of the district government as the funder to always monitor the development nets in the village. village financial managers because there is no transparent reporting system for village fund budgets for development. This resulted in the processing of village funds being hampered and delayed in making the village budget plan $(R A B)$ to immediately distribute village finances for development. The Financial Distribution Service Information System for Development can provide reporting and management of village funds for development. The Information System for Financial Distribution Services for Development can be accessed by admin, village heads and users via a web browser. The Financial Distribution Service Information System for Development has a view and design that can be easily understood and operated by the admin of Srikaya Hamlet, Sukadana Tengah Village, Sukadana District, East Lampung Regency. Reporting on the submission of a budget plan (RAB) can easily be submitted to the village head. By using the Financial Distribution Service Information System for Development, the community can see the cost budget plan (RAB) report in a transparent manner via a web browser that has been authorized by the village head The test results using Boundary Value Analysis (BVA) the feasibility of the Financial Distribution Service Information System for Development Information System is said to be feasible for used.
\end{abstract}

Keywords: Budget, Village Finance, Financial Reporting, Information Systems, Transparency

\begin{abstract}
Abstrak
Dana desa bersumber dari anggaran pendapatan dan belanja negara yang diatur oleh peraturan pemerintah indonesia nomor 60 tahun 2014. Dana tersebut digunakan untuk kegiatan desa dan pembangunan. Dalam beberapa situasi penggunaan Alokasi dana Desa ini rawan terhadap penyelewengan dana oleh pihak yang seharusnya dipercaya oleh masyarakat dalam membangun desa menjadi lebih maju dan berkembang. Pentingnya peran masyarakat sebagai pengawas langsung dan tidak lepas dari peran pemerintah kabupaten selaku pemberi dana untuk selalu memonitor jalanya pembangunan di desa. pengelola keuangan desa karena tidak adanya sistem pelaporan yang transpansi anggaran dana desa untuk pembangunan. Hal ini yang mengakibatkan proses pengolahan dana desa menjadi terhambat dan terlambat dalam pembuatan rencana anggara biaya (RAB) desa untuk segera didistribusikan keuangan desa untuk pembangunan. Sistem Informasi Pelayanan Distribusi Keuangan untuk Pembangunan dapat memberikan pelaporan dan pengelolaan dana desa untuk pembangunan. Sistem Informasi Pelayanan Distribusi Keuangan untuk Pembangunan dapat diakses oleh admin, kepala desa dan user melalui web browser. Sistem Informasi Pelayanan Distribusi Keuangan untuk Pembangunan memiliki tampiran dan rancangan yang dapat mudah
\end{abstract}


dipahami dan dioperasikan oleh admin Dusun Srikaya Desa Sukadana Tengah Kecamatan Sukadana Kabupaten Lampung Timur. Pelaporan pengajuan rencana anggaran biaya (RAB) dapat mudah disampaikan kepada kepala desa. Dengan menggunakan Sistem Informasi Pelayanan Distribusi Keuangan untuk Pembangunan masyarakat dapat melihat laporan rencana anggaran biaya (RAB) secara transfaransi melalui web browser yang telah diotorisasi oleh kepala desa. Hasil pengujian menggunakan Boundary Value Analysis (BVA) kelayakan fungsionalitas Sistem Informasi Pelayanan Distribusi Keuangan untuk Pembangunan dikatakan layak untuk digunakan.

Kata Kunci: Anggaran, Keuangan Desa, Pelaporan Keuangan, Sistem Informasi, Transparansi.

\section{To cite this article:}

Sinta Yana, Rakhmat Dedi Gunawan, Arief Budiman. (2020). SISTEM INFORMASI PELAYANAN DISTRIBUSI KEUANGAN DESA UNTUK PEMBANGUNAN (STUDY KASUS : DUSUN SRIKAYA). Jurnal Informatika dan Rekayasa Perangkat Lunak, Vol(1) $\operatorname{No(2),~}$ 254-263.

\section{PENDAHULUAN}

Teknologi informasi dan komunikasi (TIK) adalah teknologi yang mencakup perangkat elektronik, komputer, dan telekomunikasi, termasuk perangkat lunak yang dapat digunakan untuk membuat, menyimpan, mengirimkan, menerjemahkan, dan memanipulasi berbagai bentuk informasi (Miswanto, Sulistiani and Damayanti, 2020).

Undang-Undang Nomor 6 Tahun 2014 Desa adalah kesatuan masyarakat hukum yang memiliki batas wilayah yang berwenang untuk mengatur dan mengurus urusan pemerintah, kepentingan masyakakat setempat berdasarkan prakarsa masyarakat, hak asal usul, dan atau hak tradisional yang diakui dan dihormati dalam sistem pemerintahan Negara Kesatuan Repuplik Indonesia. Berdasarkan Undang-Undang yang sama tentang desa menyatakan Penata usahaan keuangan pemerintah desa terpisah dari keuangan pemerintah kabupaten. Pemisahan dalam penata usahaan keuangan desa tersebut bukan hanya pada keinginan untuk melimpahkan kewenangan dan pembiayaan dari pemerintah pusat kepada pemerintah daerah, tetapi yang lebih penting adalah keinginan untuk meningkatkan efisiensi dan efektifitas pengelolaan sumber daya keuangan dalam rangka peningkatan kesejahteraan dan pelayanan kepada masyarakat (Undang-Undang Nomor 6, 2014).

Berdasarkan undang - undang yang sama disetiap desa diberikan Alokasi Dana Desa (ADD) setiap tahun dengan jumlah tertentu sesuai dengan letak geografis desa, jumlah penduduk dan angka kematian. Dana desa bersumber dari anggaran pendapatan dan belanja negara yang diatur oleh peraturan pemerintah indonesia nomor 60 tahun 2014. Dana tersebut digunakan untuk kegiatan desa dan pembangunan. Dalam beberapa situasi penggunaan Alokasi dana Desa ini rawan terhadap penyelewengan dana oleh pihak yang seharusnya dipercaya oleh masyarakat dalam membangun desa menjadi lebih maju dan berkembang. Pentingnya peran masyarakat sebagai pengawas langsung dan tidak lepas dari peran pemerintah kabupaten selaku pemberi dana untuk selalu memonitor jalanya pembangunan di desa. Karena sebagian besar Alokasi Dana Desa diperuntukan bagi pembangunan desa maka mulai dari proses perencanaan ADD, pengelolaan ADD, hingga pelaporannya haruslah dilakukan sesuai dengan prosedur yang berlaku. Sehingga nantinya diharapkan dengan dana ADD ini dapat menciptakan pembangunan yang merata dan bermanfaat bagi masyarakat desa (Atmadja and Saputra, 2017).

Hasil wawancara Kepala Dusun Srikaya Desa Sukadana Tengah Kecamatan Sukadana Kabupaten Lampung Timur dalam proses mengalokasikan dana desa bagian sekretaris desa membuat rencana anggaran biaya (RAB) yang akan diberikan oleh kepala desa, setiap RAB dicetak dan diajukan oleh kepala desa untuk diotorisasi, jika RAB tidak disetujui maka sekretaris desa harus mengubah dan mencetak ulang sehingga menghabiskan banyak kertas untuk membuat RAB yang belum disetujui, sering terjadinya kesulitan untuk menemukan data dan kehilangan file sering terjadi karena banyaknya file dan folder yang disimpan yang menyebabkan perlunya pemembuatan file baru yang akan menghabiskan banyak waktu, sering terjadi pro dan konta antara masyakat dan pengelola keuangan desa karena tidak adanya sistem pelaporan yang transpansi anggaran dana desa untuk pembangunan (Andriyanto, Baridwan and Subekti, 2019). Hal ini yang mengakibatkan proses pengolahan dana desa menjadi terhambat dan terlambat dalam pembuatan rencana anggara biaya (RAB) desa untuk segera didistribusikan keuangan desa untuk pembangunan. Dengan menggunakan Sistem Informasi Pelayanan Distribusi Keuangan untuk Pembangunan masyarakat dapat melihat laporan rencana anggaran biaya (RAB) secara transfaransi melalui web browser yang telah diotorisasi oleh kepala desa. 


\section{TELAAH PUSTAKA}

\section{Web}

Menurut Abdulloh menyatakan "Web merupakan kumpulan halaman yang berisi data digital baik berupa teks, gambar, animasi, suara dan video atau gabungan dari semuanya yang disediakan melalui jalur koneksi internet sehingga dapat diakses dan dilihat oleh semua orang diseluruh dunia” (Abdulloh, 2018).

\section{Informasi}

Menurut Sutabri menyatakan "Informasi merupakan data yang telah diklasifikasikan atau diolah atau diinterprestasikan untuk digunakan dalam proses pengambilan keputusan”. Sistem pengolahan informasi akan akan mengolah data data menjadi informasi atau mengolah data dari bentuk tak berguna menjadi berguna bagi yang menerimanya. Nilai informasi berhubungan dengan keputusan. Bila tidak ada pilihan atau keputusan maka informasi tidak diperlukan (Sutarbi, 2012).

\section{Keuangan}

Menurut Jatmiko menyatakan "Keuangan adalah sumber kehidupan bagi perusahaan yang fokus dalam bidang bisnis". Tidak akan ada aktivitas bisnis yang bisa berlangsung tanpa adanya faktor uang. Maka dari itu, jika ada pendapat yang menyatakan bahwa bisnis pasti membutuhkan uang, itu merupakan pendapat yang benar karena bisnis tujuannya untuk menghasilkan lebih banyak uang (Jatmiko, 2017)

\section{METODE PENELITIAN}

\section{Tahapan Penelitian}

Kegiatan penelitian secara ilmiah, sistematis dan logis proses memperoleh atau memperoleh pengetahuan atau memecahkan masalah yang dihadapi (Ahdan and Setiawansyah, 2020). Dalam penelitian di bidang apapun, tahapan-tahapan tersebut biasanya memiliki kesamaan, meskipun peneliti biasanya memodifikasi tahapan tertentu dalam proses implementasi sesuai dengan kondisi dan situasi yang dihadapinya, tanpa mengabaikan prinsipprinsip umum yang digunakan dalam proses penelitian (Setiawansyah, Sulistiani and Darwis, 2020).

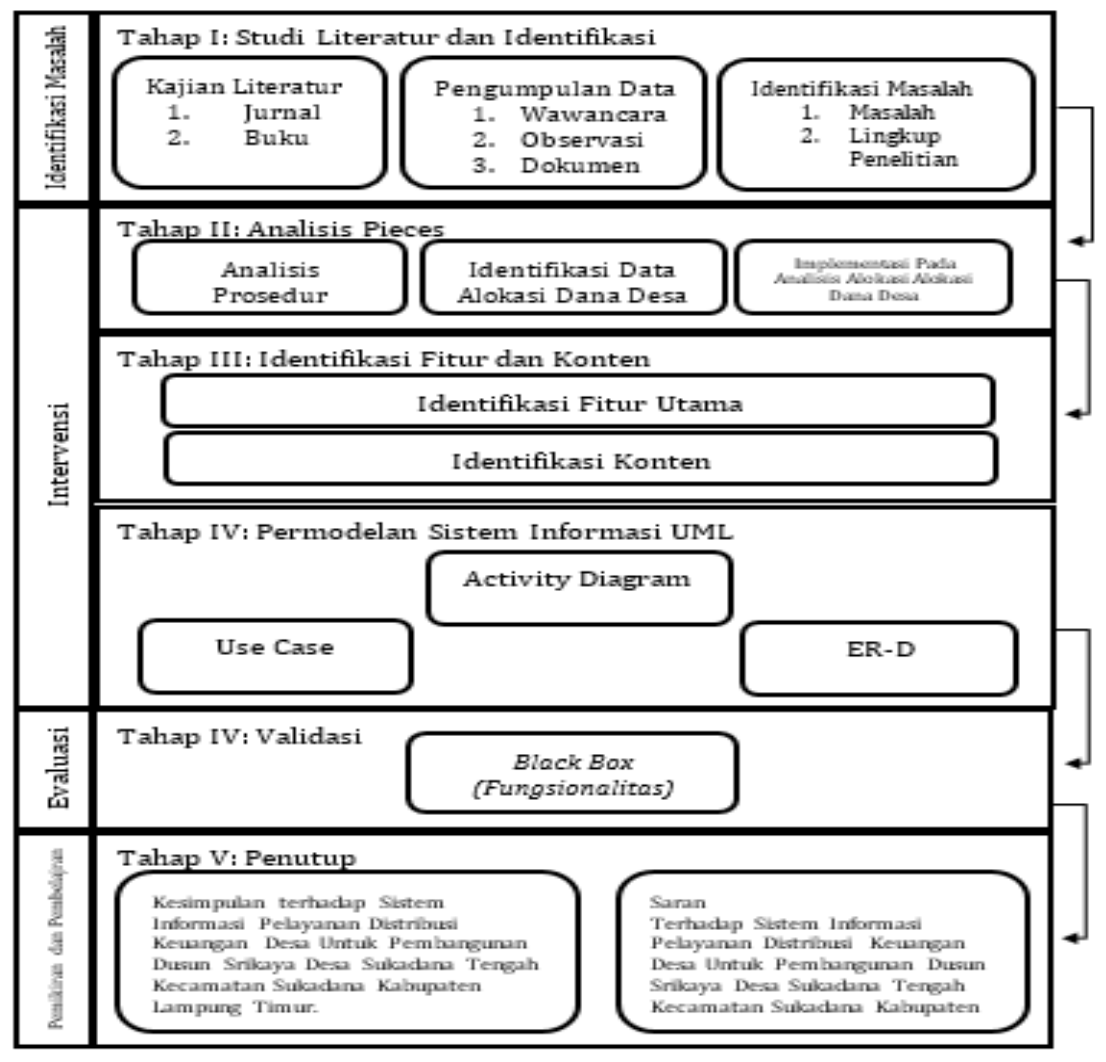


Gambar 1. Tahapan Penelitian

\section{Teknik Pengumpulan Data}

1. Wawancara dilakukan dengan 3 narasumber sesuai dengan kebutuhan dan kedudukan jabatan. Berikut adalah daftar dan jabatan narasumber : Edi Yusuf selaku Kepala Desa Sukadana Tengah, Latif Arifin selaku Sekretaris dan bendahara keuangan, dan Bahak Udin selaku Kepala Dusun Srikaya

2. Observasi Pengamatan secara langsung pada proses pendistribusian dana Desa pada Dusun Srikaya Desa Sukadana Tengah Kecamatan Sukadana Kabupaten Lampung Timur dan kegiatan pembangunan desa serta peran masyarakat, serta pengurus desa dalam kegiatan tersebut.

\section{Metode Analisis PIECES}

Pada tahap ini dilakukan analisis terhadap kebutuhan kebutuhan sistem dari perbandingan sistem lama dengan sistem baru yang akan diajukan dalam penelitian ini (Megawaty et al., 2020).

Tabel 1. Tabel Sistem Analisis Pieces

\begin{tabular}{|c|c|c|}
\hline Jenis Analisis & Sistem Lama & Sistem Yang Diusulkan \\
\hline $\begin{array}{l}\text { Analisis } \\
\text { Kinerja } \\
\text { (Performance) }\end{array}$ & $\begin{array}{l}\text { Masyarakat banyak yang tidak tahu } \\
\text { informasi tentang alokasi dana desa. }\end{array}$ & $\begin{array}{l}\text { 1. Pada sistem ini masyarakat dimudahkan dalam } \\
\text { mencari informasi distribusi alokasi dana desa } \\
\text { hanya dengan membuka web. } \\
\text { 2. Masyarakat dapat memberikan komentar kritik } \\
\text { dan saran secara online }\end{array}$ \\
\hline $\begin{array}{l}\text { Analisis } \\
\text { Kinerja } \\
\text { (Performance) }\end{array}$ & $\begin{array}{l}\text { Masyarakat banyak yang tidak tahu } \\
\text { informasi tentang alokasi dana desa. }\end{array}$ & $\begin{array}{l}\text { 1. Pada sistem ini masyarakat dimudahkan dalam } \\
\text { mencari informasi distribusi alokasi dana desa } \\
\text { hanya dengan membuka web. } \\
\text { 2. Masyarakat dapat memberikan komentar kritik } \\
\text { dan saran secara online }\end{array}$ \\
\hline $\begin{array}{l}\text { Analisis } \\
\text { Informasi } \\
\text { (Information) }\end{array}$ & $\begin{array}{l}\text { Disistem lama fasilitas } \\
\text { pemberitahuan baru diinformasikan } \\
\text { hanya melalui surat edaran atau } \\
\text { telephone yang disampaikan kepada } \\
\text { kepala desa atau sekertaris desa } \\
\text { kemudian baru disampaikan ke } \\
\text { warga }\end{array}$ & $\begin{array}{l}\text { Pada sistem ini masyarakat yang ingin mengetahui } \\
\text { informasi alokasi dana desa terbaru dapat dicek } \\
\text { melalui sistem, sehingga lebih menghemat waktu } \\
\text { dan informasi yang disampaikan lebih akurat. }\end{array}$ \\
\hline $\begin{array}{l}\text { Analisis } \\
\text { Ekonomi } \\
\text { (Economy) }\end{array}$ & $\begin{array}{l}\text { Pengurus desa sering kali } \\
\text { direpotkan dengan kertas yang } \\
\text { banyak terbuang akibat data laporan } \\
\text { RAB masih direvisi, hal itu } \\
\text { membuat biaya dan waktu yang } \\
\text { dibutuhkan lebih banyak. }\end{array}$ & $\begin{array}{l}\text { Dengan sistem web yang dirancang ini pengurus } \\
\text { desa dapat meminimalisir terbuangnya banyak } \\
\text { kertas yang digunakan untuk revisi laporan RAB. }\end{array}$ \\
\hline $\begin{array}{l}\text { Analisis } \\
\text { Pengendalian } \\
\text { (Control) }\end{array}$ & $\begin{array}{l}\text { Pada sistem lama pengajuan RAB } \\
\text { kepada kepala desa masih } \\
\text { menggunakan sistem manual sehingga } \\
\text { memakan waktu yang lama. }\end{array}$ & $\begin{array}{l}\text { Pada sistem yang diusulkan proses pengajan RAB } \\
\text { sudah bisa dilakukan dengan cara online sehingga } \\
\text { lebih memudahkan pengurus desa dan kepala desa } \\
\text { dalam proses pengajuan RAB. }\end{array}$ \\
\hline $\begin{array}{l}\text { Analisis } \\
\text { Efisiensi } \\
\text { (Eficiency) }\end{array}$ & $\begin{array}{l}\text { Pada sistem lama pengurus desa yang } \\
\text { mengajukan RAB membutuhkan } \\
\text { waktu berhari hari sampai diacc oleh } \\
\text { kepala desa jika sewaktu2 kepala desa } \\
\text { sedang ada tugas di luar kota, hal ini } \\
\text { dapat merugikan pengurus desa dari } \\
\text { segi waktu dan biaya. }\end{array}$ & $\begin{array}{l}\text { Pada sistem yang diusulkan kepala desa dapat } \\
\text { melihat langsung pengajuan RAB melalui web } \\
\text { sehingga ketika ada revisi atau sudah di acc bisa } \\
\text { langsung diterima oleh pengurus desa. }\end{array}$ \\
\hline
\end{tabular}




\section{HASIL DAN PEMBAHASAN}

\section{Use case Diagram}

Use case yang akan dikembangkan terdiri 2 aktor yaitu admin dan pengguna. Rancangan use case diagram dapat dilihat pada Gambar 2 sebagai berikut:

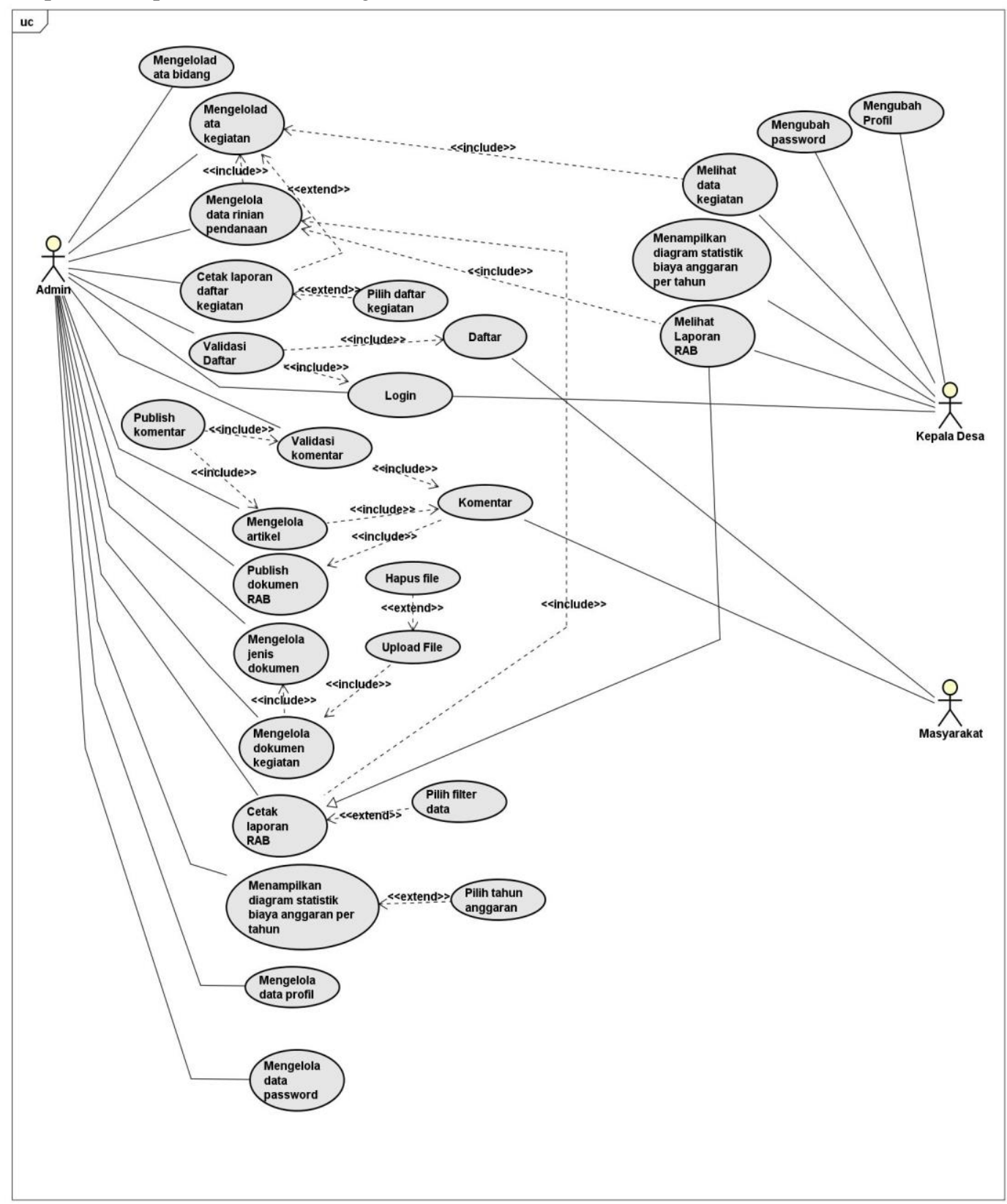

Gambar 2. Usecase Diagram

\subsection{Implementasi Sistem}

Tahap penggunaan sistem ini dilakukan setelah sistem selesai dievaluasi, kemudian peneliti melaksanakan pelatihan terhadap admin yang menggunakan sistem, dengan memberi pengertian dan pengetahuan yang cukup tentang sistem yang akan diterapkan pada Dusun Srikaya. Hal ini dimaksudkan agar membantu pihak Dusun 
Srikaya dalam memberikan informasi mengenai alokasi dana desa, sehingga tujuan sistem yang telah dibuat ini dapat tercapai. Sistem yang peneliti buat dapat membantu dalam memberikan informasi serta sebagai transparasi kepada masyarakat agar dapat melihan dan memberikan tanggapan atas alokasi dana desa.

Halaman awal admin terdapat dua field yaitu masukan username dan password. Apabila username dan password benar maka admin akan masuk kedalam sistem, jika username dan password salah maka admin tidak dapat masuk kedalam sistem. Tampilan menu awal admin dapat dilihat pada Gambar 3. berikut ini :

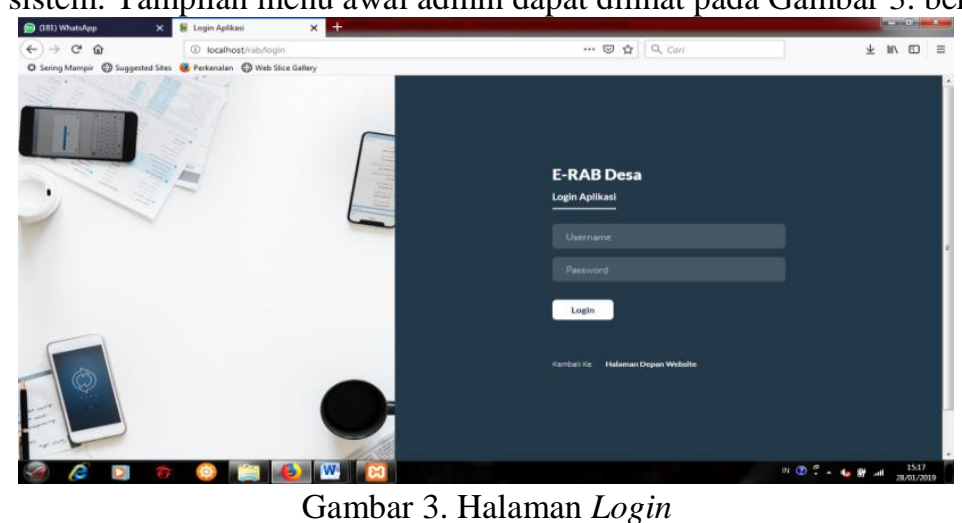

Setelah berhasil login kedalam sistem maka admin langsung masuk ke halaman beranda. Pada halaman beranda terdapat informasi admin dan Desa Srikaya Kecamatan Sukadana Tengah. Tampilan halaman beranda dapat dilihat pada Gambar 4. berikut ini :

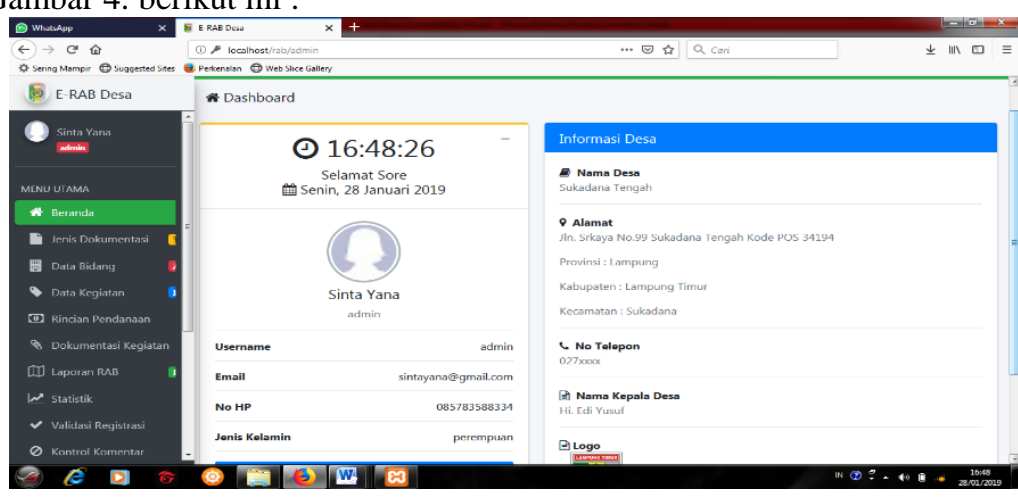

Gambar 4. Halaman Beranda

Pada halaman jenis dokumentasi admin dapat membuat judul dokumentasi, dan jenis dokumentasi berupa gambar dan dokumen. Dan pada tabel jenis dokumen admin dapat mengubah dan menghapus data dokumen atau gambar yg telah dibuat tadi. Halaman jenis dokumentasi dapat dilihat pada Gambar 4.10 berikut ini :

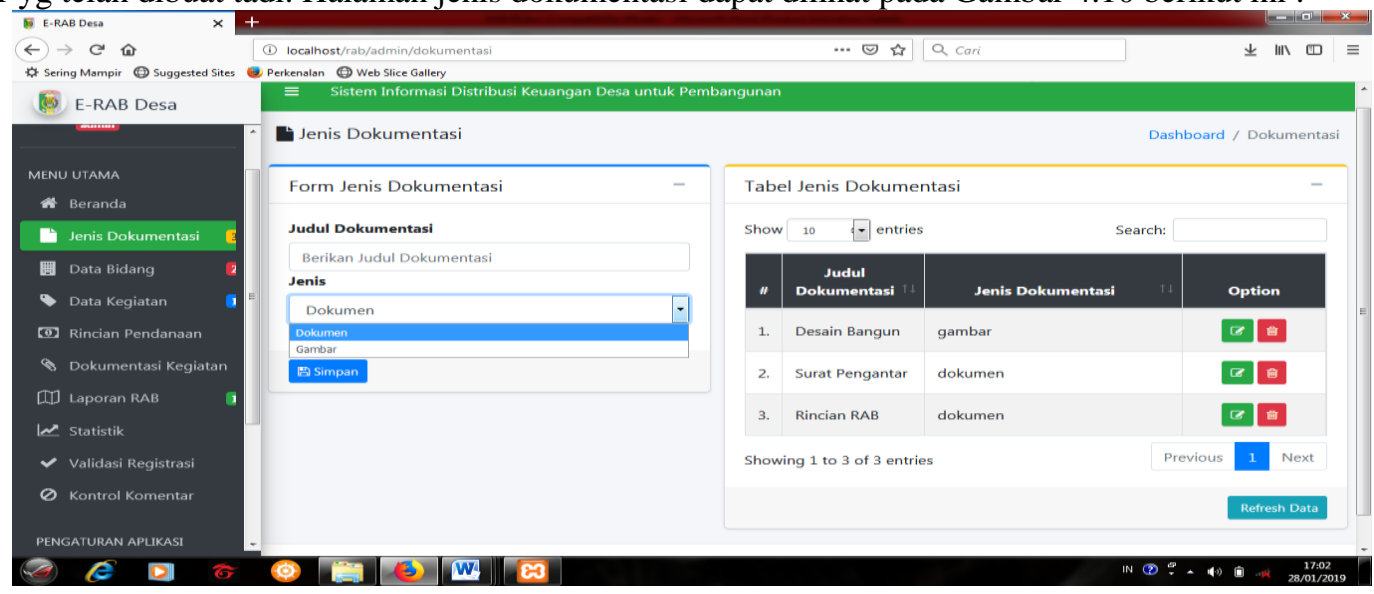

Gambar 5. Halaman Jenis Dokumentasi 
Pada halaman rincian pendanaan admin dapat menambahkan rincian dana kegiatan dengan cara memilih kegiatan pada info kegiatan, kemudian pada form rincian pendanaan admin harus menginputkan kode rekening, jenis pendanaan, uraian, volume, satuan dan harga satuan, selanjutnya klik tombol tambah rincian dana. Setelah itu pada tabel rincian dana akan muncul rincian dana yg telah dibuat tadi dan sistem akan menghitung total rincian dana secara otomatis. Halaman rincian dana dapat dilihat pada Gambar 6. berikut ini :

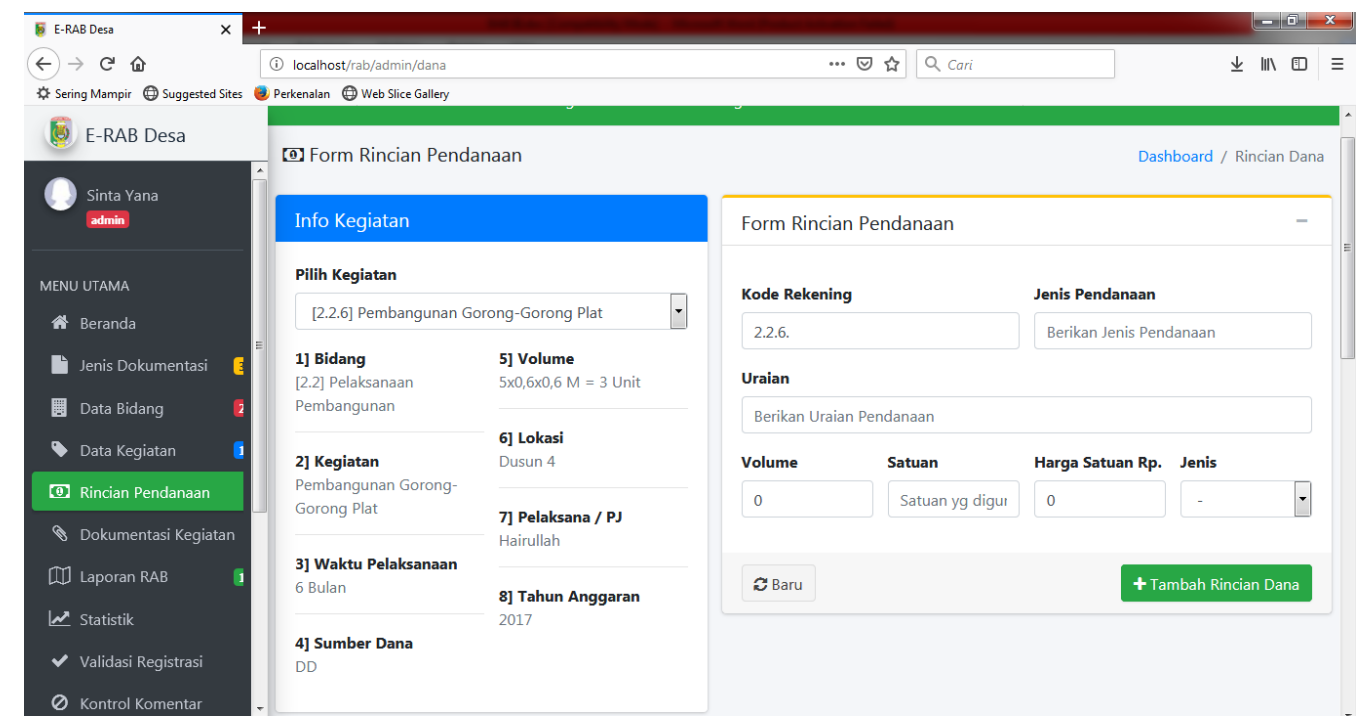

Gambar 6. Halaman Rincian Pendanaan

Pada halaman laporan RAB admin dapat mencetak rancangan anggaran biaya pada filter data, kemudian pada tabel daftar RAB adminjuga dapat melihat laporan RAB yang telah disetujui oleh kepala desa. Halaman laporan RAB dapat dilihat pada Gambar 7. berikut ini :

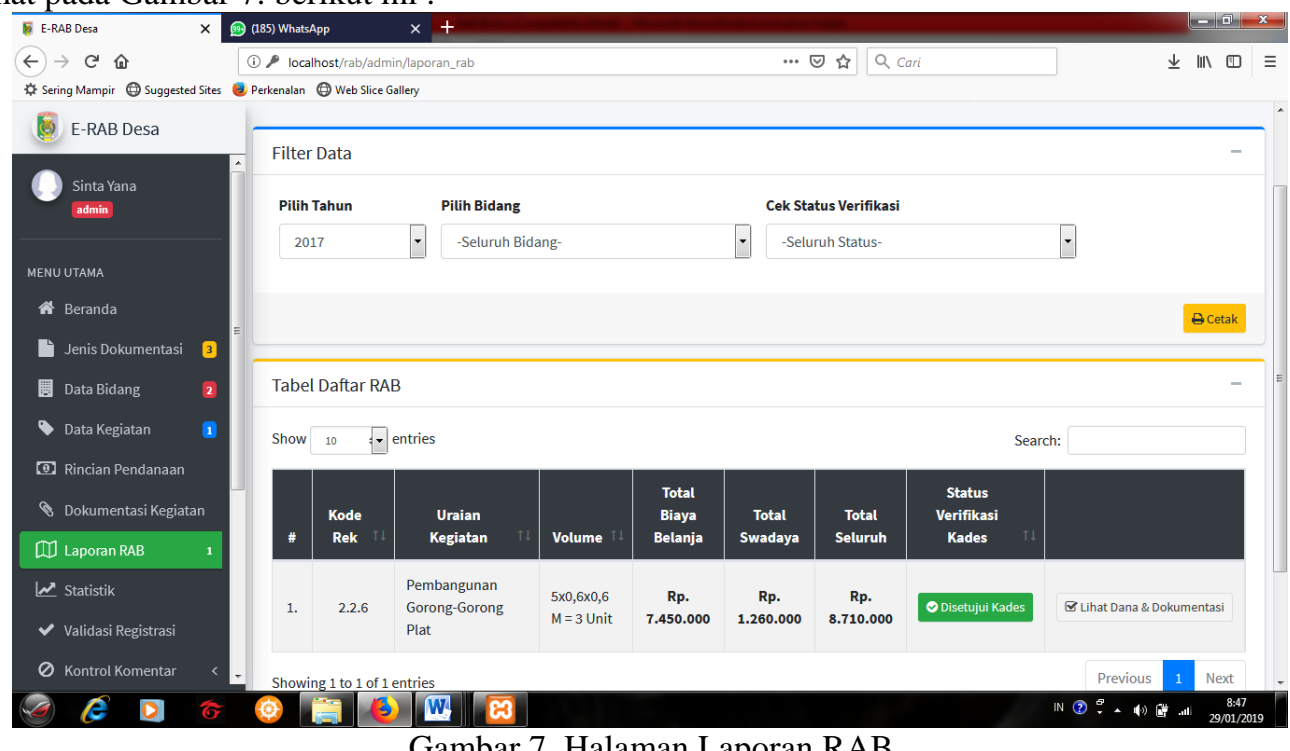

Gambar 7. Halaman Laporan RAB

\subsection{Pengujian Sistem}

Pengujian sistem dilakukan oleh pihak yang mempunyai pemahaman terhadap teknik informatika sebanyak dua responden. Perhitungan pengujian fungsionalitas menggunakan metode BVA (boundary value analysis) yang 
diuji berdasarkan form admin, kepala desa dan user. Dari hasil pengujian fungsionalitas diperoleh hasil yang sama bahwa semua fitur dari Sistem Informasi Pelayanan Distribusi Keuangan Untuk Pembangunan berjalan dengan baik sesuai dengan fungsi yang diharapkan. Selanjutnya sistem dapat diimplementasi (diterapkan). Form pengujian dapat dilihat pada daftar lampiran.

\begin{tabular}{|c|c|c|c|}
\hline & & Ya & Tidak \\
\hline 1 & $\begin{array}{l}\text { Apakah fungsi tombol login untuk dapat masuk kedalam sisitem pada form login sudah } \\
\text { berfungsi? }\end{array}$ & 2 & 0 \\
\hline 2 & Apakah fungsi tombol simpan pada data jenis dokumentasi sudah berfungsi? & 2 & 0 \\
\hline 3 & Apakah fungsi tombol ubah pada data jenis dokumentasi sudah berfungsi? & 2 & 0 \\
\hline 4 & Apakah fungsi tombol hapus pada data jenis dokumentasi sudah berfungsi? & 2 & 0 \\
\hline 5 & Apakah fungsi tombol simpan pada data bidang sudah berfungsi? & 2 & 0 \\
\hline 6 & Apakah fungsi tombol ubah pada data bidang sudah berfungsi? & 2 & 0 \\
\hline 7 & Apakah fungsi tombol hapus pada data bidang sudah berfungsi? & 2 & 0 \\
\hline 8 & Apakah fungsi tombol tambah pada data kegiatan sudah berfungsi? & 2 & 0 \\
\hline 9 & Apakah fungsi tombol cetak pada form data kegiatan sudah berfungsi? & 2 & 0 \\
\hline 10 & Apakah fungsi tombol refresh pada form data kegiatan sudah berfungsi? & 2 & 0 \\
\hline 11 & Apakah fungsi tombol tambah pada form rincian pendanaan sudah berfungsi? & 2 & 0 \\
\hline 12 & Apakah fungsi tombol ubah pada form rincian pendanaan sudah berfungsi? & 2 & 0 \\
\hline 13 & Apakah fungsi tombol hapus pada form rincian pendanaan sudah berfungsi? & 2 & 0 \\
\hline 14 & Apakah fungsi tombol reset pada form rincian pendanaan sudah berfungsi? & 2 & 0 \\
\hline 15 & Apakah fungsi tombol baru pada form data dokumentasi kegiatan sudah berfungsi? & 2 & 0 \\
\hline 16 & Apakah fungsi tombol upload pada form data dokumentasi kegiatan sudah berfungsi? & 2 & 0 \\
\hline 17 & Apakah fungsi tombol hapus pada form data dokumentasi sudah berfungsi? & 2 & 0 \\
\hline 18 & Apakah fungsi tombol refresh pada form data dokumentasi sudah berfungsi? & 2 & 0 \\
\hline 19 & Apakah fungsi tombol cetak pada laporan RAB sudah berfungsi? & 2 & 0 \\
\hline 20 & Apakah fungsi tombol reftresh pada laporan RAB sudah berfungsi? & 2 & 0 \\
\hline 22 & Apakah fungsi tombol hapus pada form validasi data sudah berfungsi? & 2 & 0 \\
\hline 23 & Apakah fungsi tombo refresh pada form validasi data sudah berfungsi? & 2 & 0 \\
\hline 24 & Apakah fungsi tombol publish pada form komentar kegiatan sudah berfungsi? & 2 & 0 \\
\hline 25 & Apakah fungsi tombol ubah pada form komentar kegiatan sudah berfungsi? & 2 & 0 \\
\hline 26 & Apakah fungsi tombol hapus pada form komentar kegiatan sudah berfungsi? & 2 & 0 \\
\hline 27 & Apakah fungsi tombol publish pada form komentar artikel sudah berfungsi? & 2 & 0 \\
\hline
\end{tabular}




\begin{tabular}{|c|l|c|c|}
\hline 28 & Apakah fungsi tombol ubah pada form komentar artikel sudah berfungsi? & 2 & 0 \\
\hline 29 & Apakah fungsi tombol hapus pada form komentar artikel sudah berfungsi? & 2 & 0 \\
\hline 30 & Apakaah fungsi tombol simpan pada form tag dan artikel sudah berfungsi? & 2 & 0 \\
\hline 31 & Apakah fungsi tombol refresh pada form tag dan artikel sudah berfungsi? & 2 & 0 \\
\hline 32 & Apakah fungsi tombol tambah pada form tag dan artikel sudah berfungsi? & 2 & 0 \\
\hline 33 & Apakah fungsi tombol refresh pada form post artikel sudah berfungsi? & 2 & 0 \\
\hline 34 & Apakah fungsi tombol tambah pada form managemen user sudah berfungsi? & 2 & 0 \\
\hline 35 & Apakah fungsi tombol refresh pada form managemen user sudah berfungsi? & 2 & 0 \\
\hline 36 & Apakah fungsi tombol ubah pada form managemen user sudah berfungsi? & 2 & 0 \\
\hline 37 & Apakah fungsi tombol simpan pada form manajemen akun profil sudah berfungsi? & 2 & 0 \\
\hline 38 & $\begin{array}{l}\text { Apakah fungsi tombol simpan pada form manajemen akun ubah password sudah } \\
\text { berfungsi? }\end{array}$ & 2 \\
\hline 39 & Apakah fungsi tombol keluar pada form keluar aplikasi sudah berfungsi? & 2 & 0 \\
\hline
\end{tabular}

Rumus :

Hasil pengujian $=(\mathrm{X} / \mathrm{Y}) \times 100 \%$

Keterangan :

Jumlah responden $=2$ responden

$\mathrm{X}=$ Diterima

$\mathrm{Y}=$ Jumlah Pertanyaan

Hasil pengujian $=(78 / 78) \times 100 \%=100 \%$

Hasil pengujian yang dilakukan bahwa fungsionalitas sistem yang dibuat sesuai fungsionalitas Sistem Informasi Pelayanan Distribusi Keuangan untuk Pembangunan dikatakan layak untuk digunakan.

\section{SIMPULAN}

Berdasarkan hasil, pembahasan, dan tingkat kelayakan fungsionalitas pengembangan Sistem Informasi Pelayanan Distribusi Keuangan untuk Pembangunan pada Dusun Srikaya Desa Sukadana Tengah Kecamatan Sukadana Kabupaten Lampung Timur penulis dapat menarik kesimpulan yaitu :

1. Sistem Informasi Pelayanan Distribusi Keuangan untuk Pembangunan dapat memberikan pelaporan dan pengelolaan dana desa untuk pembangunan. Sistem Informasi Pelayanan Distribusi Keuangan untuk Pembangunan dapat diakses oleh admin, kepala desa dan user melalui web browser. Sistem Informasi Pelayanan Distribusi Keuangan untuk Pembangunan memiliki tampiran dan rancangan yang dapat mudah dipahami dan dioperasikan oleh admin Dusun Srikaya Desa Sukadana Tengah Kecamatan Sukadana Kabupaten Lampung Timur. Pelaporan pengajuan rencana anggaran biaya (RAB) dapat mudah disampaikan kepada kepala desa. Dengan menggunakan Sistem Informasi Pelayanan Distribusi Keuangan untuk Pembangunan masyarakat dapat melihat laporan rencana anggaran biaya (RAB) secara transfaransi melalui web browser yang telah diotorisasi oleh kepala desa.

2. Dalam pengujian menggunakan Boundary Value Analysis (BVA) kelayakan fungsionalitas Sistem Informasi Pelayanan Distribusi Keuangan untuk Pembangunan dikatakan layak untuk digunakan.

\section{UCAPAN TERIMA KASIH}


Puji syukur penulis panjatkan kepada Allah SWT, karena atas berkat dan rahmat-Nya, penulis dapat menyelesaikan penelitian ini. Penulisan Penulis menyadari bahwa, tanpa bantuan dan bimbingan dari berbagai pihak, dari masa perkuliahan sampai pada penyusunan penelitian ini. Oleh karena itu, penulis mengucapkan terima kasih kepada:

1. Bapak Dr.H.M. Nasrullah Yusuf S.E, M.B.A., selaku Rektor Universitas Teknokrat Indonesia;

2. Bapak Dr. H. Mahathir Muhammad, S.E., M.M., selaku Dekan Fakultas Teknik dan Ilmu Komputer, Universitas Teknokrat Indonesia;

3. Ibu Dyah Ayu Megawaty, M. Kom. selaku Ketua Program S1 Informatika, Fakultas Teknik dan Ilmu Komputer, Universitas Teknokrat Indonesia;

\section{REFERENSI/DAFTAR PUSTAKA}

Abdulloh, R. (2018) 7 in 1 Pemrograman Web Untuk Pemula. Elex Media Komputindo.

Ahdan, S. and Setiawansyah, S. (2020) 'Pengembangan Sistem Informasi Geografis Untuk Pendonor Darah Tetap di Bandar Lampung dengan Algoritma Dijkstra berbasis Android', Jurnal Sains dan Informatika: Research of Science and Informatic, 6(2), pp. 67-77.

Andriyanto, D., Baridwan, Z. and Subekti, I. (2019) 'Anteseden perilaku penggunaan e-budgeting: Kasus sistem informasi keuangan desa di Banyuwangi, Indonesia’, Jurnal Dinamika Akuntansi Dan Bisnis, 6(2), pp. 151-170.

Atmadja, A. T. and Saputra, A. K. (2017) 'Pencegahan Fraud dalam Pengelolaan Keuangan Desa', Jurnal Ilmiah Akuntansi dan Bisnis, 12(2), pp. 7-16.

Jatmiko, D. P. (2017) Pengantar Manajemen Keuangan: Diandra Kreatif. Diandra Kreatif.

Megawaty, D. A. et al. (2020) 'SISTEM MONITORING KEGIATAN AKADEMIK SISWA', 14(2), pp. 98-101.

Miswanto, Sulistiani, H. and Damayanti (2020) 'PENERAPAN METODE COST AND BENEFIT ANALYSIS DALAM PENGUKURAN INVESTASI TEKNOLOGI INFORMASI ( STUDY KASUS : CV LAUT SELATAN JAYA ) The Application of Cost and Benefit Analysis Methods in Measuring Information Technology Investment ( Case Study: CV Laut Sel', Jurnal Tekno Kompak, 14(1), pp. 54-61.

Setiawansyah, Sulistiani, H. and Darwis, D. (2020) 'Penerapan Metode Agile untuk Pengembangan Online Analytical Processing ( OLAP ) pada Data Penjualan ( Studi Kasus : CV Adilia Lestari )', Jurnal CoreIT, 6(1), pp. 50-56.

Sutarbi, T. (2012) 'Konsep Sistem Informasi', Yogyakarta: CV. Andi Offset.

Undang-Undang Nomor 6 (2014) 'tahun 2014 tentang Desa'. 